\title{
Grid-quantification study on the effect of rapid urbanization on hydrological processes
}

\author{
Fan Yang ${ }^{1}$, Chenchen Zhao ${ }^{1}$, Jingyi Wang ${ }^{1}$, Chengshuai Liu ${ }^{1}$, Yue Sun ${ }^{1}$, shan-e-hyder \\ Soomro ${ }^{1}$, and caihong $\mathrm{hu}^{2}$ \\ ${ }^{1}$ Zhengzhou University \\ ${ }^{2}$ College of Water Conservancy \& Environmental
}

January 19, 2022

\begin{abstract}
Hydrological processes such as evaporation, infiltration, and runoff are affected not only by natural climate change but also by land cover and soil conditions. The impact of urbanization on the key elements of the hydrological process is worth studying in context of rapid urbanization. This paper combines the soil-land use index grid and the GSSHA model to quantitatively study the impact of land use on urban hydrological processes under the background of the changing urbanization stage. The results show that with the increase in land development and utilization activities, the hydrological process will transform. When grassland and woodland are converted to construction land, the changes in runoff, infiltration, and evaporation are the largest. The runoff depth increased by $0.94 \times 10-1^{\sim} 2.42 \times 10-1 \mathrm{~mm} / \mathrm{km}^{2}$, infiltration depth decreased by $0.80 \times 10-1^{\sim} 2.18 \times 10-1 \mathrm{~mm} / \mathrm{km}{ }^{2}$, evaporation decreased by $0.14 \times 10-1^{\sim} 0.28 \times 10-1 \mathrm{~mm} / \mathrm{km}^{2}$. In the transition from forest land to grassland, from cultivated land to forest land, and from cultivated land to grassland, the increase of infiltration contributed over $80 \%$ to the decrease of runoff process. This provides a scientific basis for future urban planning and sponge city construction.
\end{abstract}

\section{Hosted file}

Grid-quantification study on the effect of rapid urbanization on hydrological processes.docx available at https://authorea.com/users/404096/articles/553334-grid-quantification-study-onthe-effect-of-rapid-urbanization-on-hydrological-processes

\section{Hosted file}

Table.docx available at https://authorea.com/users/404096/articles/553334-gridquantification-study-on-the-effect-of-rapid-urbanization-on-hydrological-processes

Hosted file

Figure.docx available at https://authorea.com/users/404096/articles/553334-gridquantification-study-on-the-effect-of-rapid-urbanization-on-hydrological-processes 